\title{
Collaborative Learning and Skills of Problem-based Learning: A Case of Nigerian Secondary Schools Chemistry Students
}

\author{
Abbas Babayi Abubakar ${ }^{1,2} \&$ Mohammad Yusof Arshad ${ }^{1}$ \\ ${ }^{1}$ Department of Educational Sciences, Mathematics and Multimedia Creative, Faculty of Education, Universiti \\ Teknologi, Malaysia, Skudai, Johor, Malaysia \\ ${ }^{2}$ Department of chemistry, Federal College of Education, Yola, Adamawa State, Nigeria \\ Correspondence: Abbas Babayi Abubakar, Department of Educational Sciences, Mathematics and Multimedia \\ Creative, Faculty of Education, Universiti Teknologi, Malaysia, 81310, Skudai, Johor, Malaysia. E-mail: \\ abbasbabayi@gmail.com
}

Received: May 27, 2015 Accepted: November 4, 2015 Online Published: November 20, 2015

doi:10.5539/ass.v11n27p53 URL: http://dx.doi.org/10.5539/ass.v11n27p53

\begin{abstract}
The role of chemistry in the development of any society cannot be overemphasized. Chemistry students are therefore expected to have improved learning and acquisition of problem solving skills to facilitate the expected development in modern society. Problem-based learning is a student-centered pedagogy which helps students develop problem solving skills and improved knowledge through collaborative and self-directed learning under teacher's guide. It is supported by Cognitive and Constructive psychologists. However the learning process in Nigeria does not produce students with the required skills and knowledge, because of traditional instructions by teachers, poor learning environment and inadequate learning facilities. The purpose of this study is to investigate the roles of teachers and students in development of collaborative learning and skills in Nigerian Secondary Schools. The study used a qualitative approach with explanatory design. Fifteen (15) chemistry students and a teacher were purposefully selected from one Senior Secondary School (16 years) as participants. The participants received 6 weeks of PBL lessons using a topic purification of water. The researchers collected data during the intervention process through observations field notes and interviews after the PBL lessons were conducted. The data were transcribed, triangulated and analyzed using content analysis. The results showed that the students have improved learning and acquisition of problem solving skills including communication, teamwork and high-order thinking skills due effective collaborative learning activities among them. It is therefore recommended that collaborative learning approach be introduced in Nigerian Secondary Schools.
\end{abstract}

Keywords: problem-based learning, collaborative learning, problem solving skills, secondary schools

\section{Introduction}

Problem-based learning (PBL) is a student-centered pedagogy where learning is through problem solving. The goals of PBL is to help students develop flexible knowledge, effective problem solving skills, intrinsic motivation, collaborative and self-directed learning (Barrows, 1996; Barrows \& Tamblyn, 1980). PBL students work in groups; identify what they already know, think of what they need to know, what they should do, how and where to access new information and solve the problem. Students will generate hypotheses, identify learning issues, seek for sources of knowledge, evaluate information obtained, reflect, integrate new knowledge and synthesize solutions to problems. Teachers will facilitate learning by supporting, guiding students to focus on learning objectives, creating suitable learning environment and monitoring the learning process (Boud \& Feletti, 1999; Tan \& Arshad, 2011). PBL is an inductive process, a better alternative strategy in teaching either at secondary schools or higher educational institutions and a major focus for educational researchers in the $21 \mathrm{st}$ century (Surif, Ibrahim, \& Mokhtar, 2013). Various studies revealed the effectiveness of PBL on many aspects of learning. Students learn on their own with very minimal interactions from the guides. It improves the meaningfulness of learning as it cut across disciplines (Savin-Baden, 2000; Palinscar, 1993). It makes student accountable to the learning process, creates connections between classrooms and everyday professional life at work places and acquire life-long learning and information management skills. Students participate fully in group learning activities, discussions, collaborations between groups, presentations of ideas and development of communication, higher-order thinking and team work skills. PBL promotes a friendly learning environment for 
both teachers and students. It developed criticality of students to ask questions, look at solutions and come to a conclusion on a learning issue (Hmelo-Silver, 2004; Kolmos \& Graaff, 2007; Tan \& Arshad, 2014).

Collaborative learning entails students debating their ideas and viewpoints on the learning issues through presentations and interactions in groups. It gives them ability to appreciate a variety of other viewpoints so that they can work successfully with people from diverse backgrounds and different viewpoints. Collaborative learning gets students actively engaged in the learning process and places more responsibility of comprehension on them; their role is shifted to a more active approach rather than being lectured and getting information passively (Scot, 2008). It is commonly agreed that communication is essential for accomplishment in all professions. Most often the first impression of an individual is based on his or her ability to speak fluently and understandably. Therefore the speaking ability of students would be evaluated most in real-life situations because it plays a pivotal role in everyday life interactions (Scot, 2008; Zare \& Othman, 2015).

Human resource development is necessary for economic survival in a knowledge based society. Today employees are expected to be well equipped with new $21^{\text {st }}$ century skills such as entrepreneurship, creativity and innovativeness for problem solving (Aminu, 2007; Nwamno \& Izuagba, 2010). As a result of increasing attention and a greater need for these skills in developing workforce, educational researchers have started to look into various techniques and methods that might improve learning and development of such skills in the class rooms. Consequently, the national policy on science and technical education requires graduates to possess both professional knowledge and skills that can help them perform adequately in their various fields of economic sub-sectors of national development (Federal Republic of Nigeria, 2000; Zare \& Othman, 2015). Nigeria needs to adapt new student-centered learning strategies to produce students with greater achievements in knowledge and skills. Thus teachers should therefore facilitate improved learning and skills acquisitions among students through active learning strategies (Adeyemi, 1990; Nwamno \& Izuagba, 2010). Pedagogical practices of the 21 century education are being practiced in most developed countries and for Nigeria to be developed in the year 2020, a change in pedagogical practice is necessary (Abbas \& Arshad, 2014).

However, nowadays teaching and learning in Nigerian Secondary Schools does not produce student with the problem solving skills that are demanded from 21 century educational institutions (Ajaja, 2005; Abbas \& Arshad, 2014). Expository methods of instruction are still widely practice where students are not free to ask questions because of the teachers' autocracy. Most teachers perceive their main roles as being sole dispenser of knowledge in the classroom. Teachers' inability to adapt student-centered learning strategies could be associated with poor learning environment, inadequate learning facilities, poor teachers' welfare and lack of teacher recognition compared to other professionals in the same civil service. (Das, 2009; Ibidapo-Obe, 2007). Consequently there were fewer interactions that can support productive learning and development of skills because passive learning does not promote conceptual understanding of scientific concepts (Abdullahi, 1982; Baharom \& Palaniandy, 2013). This research therefore investigates how the necessary skills could be developed through collaborative learning in Nigerian Secondary Schools.

\section{Research Objectives}

The research aims to investigate collaborative learning and skills acquisition, and research questions are:

(i.)What are the roles of teachers and students in developing collaborative learning?

(ii.)What are the roles of teachers and students in developing problem solving skills?

\section{Research Methodology}

This research has a qualitative approach and explanatory design. Fifteen (15) chemistry students (16 years) divided into three groups and one teacher were purposefully selected from a Senior Secondary School in Yola, Adamawa state of Nigeria as participants. The participants went through PBL process using real-life problems (cholera, pipelines blockages and washing problems) with a study topic "purification of water". An intervention period of 6 weeks was carried out by the researchers. The researchers collected data during the learning process through observations field notes of the learning processes and interview using unstructured questions to a focus group of 5 students after the learning processes. The data were transcribed, triangulated and analyzed using content analysis.

\section{Results and Discussions}

The data collected were organized and coded into themes using content analysis as follows: Selecting relevant ideas, identifying repeated ideas, organizing the repeated ideas into themes and forming the narrative to describe the research questions. Research question (i), states: 
(i.)What are the roles of teachers and students in developing collaborative learning?

\subsection{Collaborative Learning}

Collaborative learning of the PBL, encouraged students to work together in groups to facilitate learning by: Setting their learning goals, working together in groups to accomplish a task, sharing of knowledge by teaching each other, assessing their learning and that of their peers, teachers also assess individual student and group achievements, teachers provide content knowledge and build on student knowledge (Kolmos \& Graaff, 2007; MacDonald \& Isaacs, 2001). As mentioned earlier the first students' activity in collaborative learning process is setting their learning goals.

\subsubsection{Students Set Their Learning Goals}

(a) Observation field notes reports on students setting their learning goals

Learning goals forms the plan for learning activities; students therefore set their goals before the learning process begins using FILA chart. The columns for learning issues "what do we need to know" and the action plan "what do we do" of the chart forms the learning goals using two problems presented by the teachers to stimulate learning as shown in Table 1.

Table 1. Students set their learning goals using FILA chart

\begin{tabular}{|c|c|c|c|}
\hline Facts & Ideas & Learning issues / needs & Action plan. \\
\hline $\begin{array}{l}\text { The information } \\
\text { obtained from the } \\
\text { problems }\end{array}$ & $\begin{array}{l}\text { What do we know? } \\
\text { Trying to understand the problem. }\end{array}$ & $\begin{array}{l}\text { What do we need to know? } \\
\text { The resources you should find to } \\
\text { solve the problem. }\end{array}$ & $\begin{array}{l}\text { What do we do? } \\
\text { Learning activities to be } \\
\text { conducted to bridge the } \\
\text { learning gaps for problem } \\
\text { solution. }\end{array}$ \\
\hline $\begin{array}{l}\text { Problem } 1 \\
\text { A man is } \\
\text { vomiting, having } \\
\text { diarrhea and is } \\
\text { dehydrated. }\end{array}$ & $\begin{array}{l}\text { The teacher introduced the } \\
\text { problems and asked these } \\
\text { facilitating questions. } \\
\text { What do you know about the } \\
\text { problem? } \\
\text { How devastating is the problem? } \\
\text { Does it affect adult or children? } \\
\text { Students deliberated and } \\
\text { concluded that: It is a medical } \\
\text { problem known as cholera; it } \\
\text { affects both adults and children but } \\
\text { so devastating on children below } \\
\text { 5years. There is need for solution. }\end{array}$ & $\begin{array}{l}\text { Teacher asked stimulating } \\
\text { question: } \\
\text { What do you need to know } \\
\text { about the problem? } \\
>\text { The students discussed and } \\
\text { resolved to have answer these } \\
\text { research questions: } \\
>\text { What are the courses of cholera? } \\
>\text { What are other signs and } \\
\text { symptoms of the cholera? } \\
>\text { How is cholera transmitted? }\end{array}$ & $\begin{array}{l}\text { Teacher facilitates student } \\
\text { group discussions on the } \\
\text { three research questions } \\
\text { with the aim of solving the } \\
\text { disease problem. } \\
>\text { How do you obtain pure } \\
\text { water for drinking? } \\
>\text { How do you maintain } \\
\text { improved environmental } \\
\text { sanitation? } \\
>\text { How do you keep good } \\
\text { personal hygiene? }\end{array}$ \\
\hline $\begin{array}{l}\text { Problem } 2 \\
\text { Pipe lines, Tabs, } \\
\text { Shower heads } \\
\text { blockages and } \\
\text { washing } \\
\text { difficulties. }\end{array}$ & $\begin{array}{l}\text { The teacher introduced the } \\
\text { problem and asked these } \\
\text { facilitating questions. } \\
\text { What do you know about the } \\
\text { problem? } \\
\text { The students critically discussed } \\
\text { and concluded that: } \\
\text { The problem is due to water } \\
\text { pollution known as water hardness. } \\
\text { It makes domestic activities } \\
\text { difficult. }\end{array}$ & $\begin{array}{l}\text { The teacher asked to stimulate } \\
\text { learning, what do you need to } \\
\text { know about the problem? } \\
\text { The students collaborated and } \\
\text { set these study questions. } \\
\text { What are the courses of these } \\
\text { blockages and washing } \\
\text { problems? } \\
\text { How does the problem affect } \\
\text { hold activities? }\end{array}$ & $\begin{array}{l}\text { The teacher encouraged } \\
\text { students to share knowledge } \\
\text { and discuss in groups on the } \\
\text { study questions and proffer a } \\
\text { solution on, how to soften } \\
\text { hard water for better house } \\
\text { hold activities. }\end{array}$ \\
\hline
\end{tabular}

(b) Student interview responses on how they set their learning goals from the chart are reflected below, each response is followed by the students' identity number made up of school name group number and student serial number in the group:

Researchers: How do you set your learning goals? 
Students: We set our group learning goals at the beginning of the process with help of our teacher. AMCS201.

We plan our learning goal using FILA chat what we already know, what we need to know and what do we do to solve problem AMCS305.

We set our learning goals to guide our learning process.... with the help of FILA chart.AMCS104.

4.1.2 Students Working Together in Groups to Accomplish Task

(a) Observation field notes reports on students working together in groups.

The students worked together as a team during collaborative learning process to achieve a common goal through teacher facilitated verbal learning interactions and activities according to groups as shown in Table 2 .

Table 2. Students work together in groups to accomplish task through learning interactions and activities

\begin{tabular}{|c|c|c|c|}
\hline $\begin{array}{c}\text { Students learning } \\
\text { process }\end{array}$ & Students group1 & Students group2 & Students group3 \\
\hline $\begin{array}{l}\text { Teacher guided verbal } \\
\text { learning } \text { interactions } \\
\text { through statements and } \\
\text { questions. }\end{array}$ & $\begin{array}{l}\text { Students individual and } \\
\text { group presentations. }\end{array}$ & $\begin{array}{l}\text { Students' questions and } \\
\text { answers interactions. } \\
\text { Student-Teacher questions and } \\
\text { answers interactions. }\end{array}$ & $\begin{array}{l}\text { Students explaining the } \\
\text { processes of water } \\
\text { purifications to peers. } \\
>\text { Students' small group } \\
\text { discussions. }\end{array}$ \\
\hline $\begin{array}{l}\text { Teacher facilitated } \\
\text { Learning activities } \\
\text { through instructions and } \\
\text { questions. }\end{array}$ & $\begin{array}{l}\text { Students compared pure } \\
\text { water brands for purity. } \\
>\text { Students modeling of } \\
\text { compounds (water)using } \\
\text { balls and sticks. } \\
\text { Students Classification of } \\
\text { water samples into soft and } \\
\text { hard water. }\end{array}$ & $\begin{array}{l}\text { D Students fill in their work sheets } \\
\text { in groups for assessment. } \\
\text { Students observations of } \\
\text { bacteria contaminated water } \\
\text { samples that courses cholera. } \\
>\text { Students observation of hard } \\
\text { water that courses problem } 2\end{array}$ & $\begin{array}{l}\text { Students group } \\
\text { identification of } \mathrm{Ca}+2 \text { and } \\
\mathrm{Mg}+2 \text { from a periodic table. } \\
>\text { Students filtering some } \\
\text { contaminated sample of } \\
\text { water using filtration set. }\end{array}$ \\
\hline
\end{tabular}

(b) Students interview responses on how they work together as a team are reflected below:

Researcher: How do you work together in your groups to accomplish task?

Students: I take part in small group discussions with my peers to solve the problemsAMCS201. I present my individual ideas to the group.AMCS104.

I answer both teachers and students questions in the groups.AMCS103.

We work together as a team through demonstration activities to solve the problem.AMCS304.

We work together as a group for learning through explanations of some learning processes in chemistry. AMCS 105.

4.1.3 Students Shared Knowledge by Teaching One Another in the Process of Collaborative Learning

(a) Observation field notes reports on students sharing knowledge in groups.

Students shared knowledge in their groups through questions and answers and explanations of their ideas to peers on some learning difficulties such as the multiple levels of chemical representations as shown in Table 3 .

Table 3. Students sharing knowledge through questions / answers and explanations

\begin{tabular}{|c|c|}
\hline Students questions & Students answers \\
\hline $\begin{array}{l}\text { What is the name of the bacteria in } \\
\text { water that courses cholera AMCS102?. }\end{array}$ & $>$ These bacteria are called vibrio-cholerae AMCS101. \\
\hline $\begin{array}{l}\text { How do the bacteria look like } \\
\text { AMCS105? }\end{array}$ & $\begin{array}{l}\text { These bacteria cannot be seen with ordinary eyes but only with a microscope } \\
\text { AMCS103. }\end{array}$ \\
\hline $\begin{array}{l}\text { How does water become hard naturally } \\
\text { AMCS103?. }\end{array}$ & $\begin{array}{l}\text { Water hardness comes from natural occurring calcium and magnesium salts which } \\
\text { are dissolved from the rocks by rain water flows. Water is harder in limestone areas } \\
\text { than those with insoluble rock such as granite. AMCS105. }\end{array}$ \\
\hline
\end{tabular}


Do the bacteria that course cholera lives only in water?
Based on my ideas the bacteria do not only live in water but also on some bad foods or fruits, and that house fly is a vector for transmitting it. Therefore we should also avoid bad foods and fruits and live in well sanitized environmentAMCS103.

When does water becomes really hard? Water become hard if it containe
120-180 mg per liter AMCS205.

How do we soften hard water?

I need explanations on micro level of chemical representation please

Another explanation please on the macro level of chemical representations
$>$ Hard water can be soften with the use of lime $\mathrm{Ca}(\mathrm{OH})_{2}$ or soda ash $\mathrm{Na}_{2} \mathrm{CO}_{3}$. The calcium and magnesium ions are precipitated as calcium carbonate $\mathrm{CaCO}_{3}$ and magnesium hydroxide $\mathrm{Mg}(\mathrm{OH})_{2}$ as follows: AMCS104.

Explanation of microscopic level of chemical representations: Water contains dissolved ions that cannot be seen with naked eye as follows: Cations : $\mathrm{Na}+$, $\mathrm{K}^{+}, \mathrm{Mg}^{2+}, \mathrm{Ca}^{2+}, \mathrm{Fe}^{2+}, \mathrm{Mn}^{2+} \mathrm{Al}^{3+}$ and anions: $\mathrm{Cl}^{-}, \mathrm{F}^{-}, \mathrm{I}^{-}, \mathrm{Br}^{-}, \mathrm{SO}_{4}^{-}, \mathrm{CO}^{3-}, \mathrm{HCO}^{3-}, \mathrm{NO}^{3-}$ and $\mathrm{NO} 2-\mathrm{AMCS} 304$. Similarly the lime dissociates in water to give calcium and hydroxyl ions as follows. AMCS302. $\mathrm{Ca}(\mathrm{OH})_{2} \rightarrow \mathrm{Ca}^{2+}+2 \mathrm{OH}^{-} \ldots$ (Equation 1).

Explanation of macroscopic level of chemical representation: The calcium ions react with the bicarbonates in water to precipitate solid calcium carbonate, this reaction can be seen with ordinary eyes as follows: AMCS203. $\mathrm{Ca} 2++2 \mathrm{HCO} 3-\rightarrow$ $\mathrm{CO} 3+\mathrm{H} 2 \mathrm{O}+\mathrm{CO} 2 \ldots$. (Equation(2). The hydroxyl ions from the lime also react with magnesium ion to precipitate solid magnesium hydroxide as followsAMCS203. $\mathrm{Mg} 2++2 \mathrm{OH}-\rightarrow \mathrm{Mg}(\mathrm{OH}) 2 \ldots$ (Equation 3).

Student sharing knowledge through teaching one another is an important process in collaborative learning because they understand better explanations from peers who they share common interest and experiences. Students can use their native language for better comprehension unlike the medium of instructions in schools which may be a second language. Students' freedom to ask questions and elicit explanations facilitates their critical thinking ability and improves learning.

(b) Students 'interview responses on sharing of knowledge in groups.

Researchers: How do you share knowledge in you group?

Students: We shared knowledge by teaching one another in our group..AMCS304.

I explain my share ideas with my peers who do not understand some learning difficulties in chemistry.AMCS103.

We share everything with peers during learning through questions and answers session.AMCS204.

Sharing the knowledge and ideas through questions and answers and explanations becomes part of our learning...AMCS202.

I shared knowledge with my peers.AMCS102.

4.1.4 Students Assessing Their Learning and That of Peers

(a) Observation field notes reports on student reflection and assessment of peers.

Assessment was carried out student worksheet and after filling the work sheets individually, the students interchanged their worksheets between groups for assessment. Every group discussed using the learning materials and teacher questions for clarification on the correct responses. Each student assesses and scores his or her peer.

(b) Students' interview responses on reflection and assessment of peers in group learning.

Researchers: How do you assess self and your peers in your group?

Students: I assess my learning and evaluate the group members through the use of work sheet...AMCS201.

We examine how much have we achieved from the set learning goals and how effective our learning strategies..AMCS302

We assess our learning and that of the peers using the work sheet exercise across groups...AMCS202.

We reflect and evaluate peers during learning because assessment is part of our learning process. AMCS101. 


\section{We measure our learning based on our plan objective or goalsAMCS205.}

\subsubsection{Teachers Assessing Individual Students and Groups Achievements}

(a) Observation field notes report on teacher assessments of the students.

Teachers assessed individual students and groups using questions and answers session and individual students' assignment on filling of the work sheet. Table 4: shows teachers' questions and students' answers in the teacher assessment process of the PBL module lessons.

Table 4. Teacher assessment of individual and groups of students through questions and answers sessions

\begin{tabular}{ll}
\hline Teacher Questions & Students Answers \\
\hline PBL module Problem 1 & $>$ (Cholera is a disease condition commonly found in dirty environment. \\
$>$ What is cholera? & $>$ Symptoms of cholera includes: vomiting, diarrhea and dehydration. \\
$>$ What are the symptoms of cholera? & $>$ Cholera is course by intake of bacteria contaminated water and foods. \\
$>$ What are courses of cholera? & $>$ We can pure water by disinfecting water. \\
$>$ How do you get pure water? & $>$ Cholera can be avoided taking pure water and safe foods. \\
$>$ How can you avoid contacting cholera? & $>$ The processes of purifying public water include: Screening, sedimentation, \\
$>$ What are the processes of purifying & precipitation, filtration, adsorption and disinfection.
\end{tabular}

\section{PBL module problem 2}

$>$ What is water?

$>$ What are the physical properties of water?

$>$ What is water hardness?

$>$ What are the problems of water hardness?

$>$ What are the processes of softening hard water?

$>$ Why hard water does not course health problems

$>$ Why ice as solid floats on water?
Water is a chemical compound; it consists of two atoms of hydrogen bonded to one atom of oxygen.

$>$ Water has molecular formula of $\mathrm{H} 2 \mathrm{O}$, molar mass of water: $18.015 \mathrm{~g} / \mathrm{mol}$, a density of $1000 \mathrm{~kg} / \mathrm{m}^{3}$, a melting point of $0{ }^{\circ} \mathrm{C}$ and a boiling point of $100{ }^{\circ} \mathrm{C}$

$>$ It is water that contains $\mathrm{Ca}^{2+}$ and $\mathrm{Mg}^{2+}$. These ions engage in reactions that leave insoluble mineral deposits. These deposits make hard water unsuitable for many uses.

> Hard water can cause scale to form in kettles, around taps and shower heads, pipelines. Hard water also course washing problems.

$>$ The process for softening hard water is known as the "lime-soda process" it is used to remove $\mathrm{Ca}^{2+}$ and $\mathrm{Mg}^{2+}$ from the water supply. The water is treated with a combination of $\mathrm{Ca}(\mathrm{OH})_{2}$, and $\mathrm{Na}_{2} \mathrm{CO}_{3}$. Calcium precipitates as $\mathrm{CaCO}_{3}$, and magnesium precipitates as $\mathrm{Mg}(\mathrm{OH})_{2}$. This removed the scale-forming cations from the water supply.

$>$ Hard water does not course health problems because calcium and magnesium ions and other minerals in hard waters are generally beneficial to health.

$>$ Ice as solid floats on water because it is less dense than water, water and ice has a densities of $1000 \mathrm{kgm}^{-3}$ and $917 \mathrm{kgm}^{-3}$ respectively.

Teacher questions play an important role in collaborative learning process because they facilitate, encourage, assess and stimulate students learning using different questions.

(b) Students interview responses on teachers' assessments through questions and answers

Researchers: How are you assessed by your teacher individually and groups?

Students: The teachers also assess my learning and group learning achievements through questions and answers with students..AMCS204.

He sometimes gives individual and group assignments of filling the work sheet as assessment..AMCS103.

Teachers evaluate every student and also the whole group.AMCS203:

Teachers guide our learning with evaluations of individual students and the group using the worksheet and questions. AMCS304.

Assessment by the teachers is also part of our learning process in this approach.AMCS101. 


\subsubsection{Teachers Provide Content Knowledge and Build on Students' Prior Knowledge}

(a) Observation field notes reports on teacher provision of content knowledge are as follows:

Teachers set the learning environment and ensured that students work together effectively to achieve the common goal. They introduced the PBL real-life problems and teach the students the social skills for effective collaboration. Teachers provide the content knowledge and instructions to students; build on their personal experiences, knowledge, strategies and link these to new knowledge during collaborative learning process. They guide students also to select more content learning materials and coach them to focus on learning objectives (Johnson, Johnson, \& Edythe, 1991).

(b) Students interview responses on teacher provision of content knowledge reports as follows

Researchers: Does teacher provide content knowledge and use your prior knowledge and experience?

Students: Yes. The teacher provide content knowledge by lecturing and continues from our prior knowledge and experiences.AMCS103.

He taught us how to socialize in group learning to achieve common goal.AMCS104.

The teachers made some explanations on how we can solve the problem through effective collaboration.AMCS303.

The teachers explain the content knowledge by lecturing in the general class and they build on our experience and prior knowledge on the problem. AMCS105.

The result revealed that PBL module lessons facilitate students' collaborative learning activities and helped them acquire improved learning and skills. The students are encouraged to set their group learning goals, work together in small groups to accomplish a task, shared knowledge and experiences and assess their learning and that of peers during group discussions. Teachers also assess individual students and groups achievements, provide the content knowledge and build on students' prior knowledge. This result is supported by another research report that the groups' learning sessions facilitate sharing of ideas, positive interdependence and cordial relationship between teachers and students. PBL provides improved student learning and acquisition of skills. Students working in small groups tend to learn more and retain the knowledge longer. In collaborative learning: students set learning goals, share knowledge by teaching each other, freely ask questions and assess their learning outcome, and actively work together in group's task under the teacher's guide (Collazos, Guerrero \& Pino, 2001; Soller \& Lesgold, 2000).

Research question 2 states:

(ii.) What are roles of teacher and students in development of problem solving skills?

\subsection{Development of Problem Solving Skills}

\subsubsection{Communication Skills}

(a) Observation field notes on students development of communication skills.

Students were seen to participate fully in group learning activities through discussions within a group and collaborations between groups through presentations of ideas. They were fully engaged in interactive learning process; sharing knowledge, asking questions and responding to students and teachers questions and explanation to peers for clarity and understanding.

(b) Some students' interview responses also described their experiences in communication skills after PBL lessons.

Researcher: How PBL lessons improve your communication ability?

Students: The group discussions in the PBL lessons improved my ability to speak confidently.AMCS201.

I answer both teachers and students questions adequately in the general class..AMCS303. Sharing of knowledge by teaching one another in our group improves the way I speak. I can now correctly present my individual ideas to the group.. AMCS101.

I have learned to communicate in a better way with my friends even outside the school. My speaking ability becomes more developed because of my interactions in PBL...AMCS105.

I feel happy when I correctly address group of people. AMCS204.

The result shows development in students' communication abilities due to collaborative learning of the PBL module lessons. It is supported by a similar research report that collaborative learning process requires students 
to work together in groups towards a common learning goal. The PBL groups' discussions sessions facilitates students sharing of knowledge by teaching each other, writing summaries of discussions for presentations and the presentations of individual and groups products or solutions. These activities improved student learning and acquisition of communication and teamwork skills (Davis, 2003; Slavin, 1987).

\subsubsection{Team Work Skills}

(a) Observation field notes reports on students' acquisition of teamwork skills.

Students were reported to be working together as a team to achieve a common learning goal through sharing of ideas, they become responsible for each other's learning and group achievement. They depended on each other to accomplish learning objectives.

(b) Students interview responses on teamwork.

Researcher: How PBL lessons develop your team work ability?

Students; PBL module group discussions stimulate my creative thinking. I feel happy and active during PBL module team work. AMCS305.

I learn the skill of working together to achieve common interest, it solve problem fasterAMCS101.

I tolerate my colleagues and respect their opinions in PBL module lessons group learning..AMCS201.

Findings from the research revealed that PBL module lessons facilitate students' development of team work skills through good working relationships and positive interdependence in their learning activities. They settled their differences amicably worked together to achieve a common objective of problem solving. Another research report by Johnson, Johnson and Edythe, (1991); Gabel, (1999) also acknowledged that PBL groups learning facilitate cordial relationship between students and teachers and encouraged students to work together towards a common learning goal. It improved student learning and acquisition of teamwork skills (Soller, Lesgold, Linton, $\&$ Goodman, 1999).

\subsubsection{Higher-Order Thinking Skills}

(a) Observation field notes reports on students' acquisition of higher-order thinking skills

Students were reported to be collaborating within and between groups for learning. They were fully engaged in activities such as analyses, evaluation and synthesis of information to find solutions to problems.

(b) Some student interview responses on PBL lessons described higher-order thinking skills

Researcher: How PBL lessons develop your higher-order thinking skills?

Students: Hummm.. I acquired some scientific skills that involves evaluation, analysis and synthesis through PBL processs..AMCS305.

I always evaluate my learning (reflection) and that of my peers during PBL group discussions....AMCS102.

I participated in the classifications and comparing of pure water brands based on quality or purity. I also took part in the modeling process of some compounds \{water, $\mathrm{H}_{2} \mathrm{O}$; Carbon (iv) oxide, $\left.\mathrm{CO}_{2}\right\}$ using balls and sticks in the learning process..AMCS205.

Finding from the research shows that PBL lessons develops students' higher-order thinking skills through it hand-on-approach in small groups' activities. Usually students brain storm on the real-life problem to come out with an acceptable solution to it. Therefore they need to critically look and properly define the problem for better understanding, evaluate, analyze it before synthesizing a suitable solution to it. The finding is in conformity with an earlier research and reports (Ajaja, 2005; National Research Council, 1987; Otuka, 2007) that higher order thinking skills involved analysis, evaluation and synthesis; these skills can be applied in different situations other than the class rooms, thus required active teaching and learning strategies. PBL as a student-centered approach provide students with the needed problem solving skills.

\section{Conclusion and Implication of the Study}

The idea of introducing real-life problems to stimulate collaborative learning and the hands-on-approach of the PBL connect knowledge and practice. It also extended class room experiences to real life in the society and enhanced professionalism in workplaces. This research revealed that PBL module lessons have develop students' collaborative learning and skills acquisition. Hence teachers should facilitate collaborative learning activities and interactions that adequately engage students in the learning process. Therefore researchers recommended collaborative approach for teaching and learning chemistry in Nigerian Secondary Schools and other higher educational institutions. 


\section{Acknowledgements}

We would like to express our sincere appreciations to the teacher and students volunteer participants of this research.

\section{References}

Abbas, B. A., \& Arshad, M. Y. (2014). The Need for Problem-based Learning in Nigerian Secondary Schools Chemistry Lessons. A Paper Presented at the $1^{\text {st }}$ International Education Postgraduate Seminar On Innovation, Issues and Challenges for Educational Sustainability (pp. 1-8) Universiti Teknologi Malaysia. Johor Bahru, Malaysia. 23-24, November.

Abdullahi, A. (1982). Science Teaching in Nigeria. Ilorin: Atoto Press Ltd.

Adeyemi, M. A. (1990). Cognitive Style: A Variable in Process Skill Development in Science. Nigeria Journal of Education Psychology, 5(1), 45-56.

Ajaja, O. P. (2005). Comparison of the Effectiveness of Three Instructional Methods (Advance Organizer, Discovery and Invention) on Exhibition of Acceptable Laboratory Behaviors. Journal of Vocational Science and Educational Development, 6(2), 16-44.

Aminu, D. M. (2007). Application of Science and Technology for Sustainable National Development. A paper Presented at a National Conference of Science Teachers Association of Nigeria (STAN). Sokoto, 21-26, August.

Baharom, S., \& Palaniandy, B. (2003). Problem-based Learning: A Process for Acquisition of Learning and Generic Skills. Proceedings of the $4^{\text {th }}$ International Research Symposium on Problem-Based Learning (pp. 47-55). Universiti Teknologi Malaysia. Kuala-Lumpur: 2-3, July.

Barrows, H. S. (1996). Problem-Based Learning in Medicine and Beyond: A brief Overview. In L. Wilkerson, \& H. Gilselaers (Eds.), Bringing Problem-Based Learning to Higher Education: Theory and Practice. San Franscisco, CA: Jossey-Bass.

Barrows, H., S., \& Tamblyn, R. M. (1980). Problem-Based Learning: An Approach to Medical Education. New York: Springer Publishing Company.

Boud, D., \& Feletti, G. (1999). The Challenge of Problem-Based Learning (2nd ed.). London: Kogan Page.

Collazos, C. A., Guerrero, L. A., \& Pino, J. A. (2001). Computational Design Principles to Support the Monitoring of Collaborative Learning Processes. Journal of Advanced Technology for Learning, 1(3), 174-180.

Das, R. C. (2009). Science Teaching in Schools. New Delhi: Sterling Publishers private Limited.

Davis, E. (2003). Prompting Middle School Science Students for Productive Reflection: Generic and Directed Prompts. Journal of the Learning Sciences, 12, 91-142.

Federal Republic of Nigeria. (2004). National Policy on Education. Lagos: NERDC.

Gabel, D. (1999). Improving Teaching and Learning through Chemistry Education Research: A look to the Future. Journal of Chemical Education, 76(4), 548-552.

Hmelo-Silver, C. E. (2004). Problem-Based Learning: What and how do students learn? Educational Psychology Review, 16, 235-266.

Ibidapo-Obe, O. (2007). The Challenges of Teacher Education in Nigeria: The University of Lagos Experience (pp. 1-11). Paper Presented at the Second Regional Research Seminar for Africa. Accra.22-24, March.

Johnson, D. W., Johnson, R. T., \& Edythe, J. (1991). Cooperation in the Classroom. Edina: Interaction Book Company.

Johnstone, A. H. (1991). Why is Science Difficult to Learn? Things are Seldom What They Seem. Journal of Computer Assisted Learning, 7(2), 75-83.

Kolmos, A., \& Graaff, E. D. (2007). Process of Changing to PBL. In E. Graaff de, \& A. Kolmos (Eds.), Management of Change: Implementation of Problem-Based and Project-Based Learning in Engineering (pp. 31-44). Rotterdam: SENSE Publisher,

MacDonald, D., \& Isaacs, G. (2001). Developing a Professional Identity through Problem-Based Learning. Teaching Education, 1(2), 315-333.

National Research Council. (1987). Education and Learning to Think. Washington: National Academy press. 
Nwamno, P., \& Izuagba, A. (2010). Teacher Education and Challenges of the Millennium Development Goals. European Journal of Social Sciences, 1(7), 91-95.

Otuka, J. O. E. (2007). The Nature and Importance of Science Education in National Development. A Paper Presented at The National Conference of Science Teachers Association of Nigeria (pp. 6-19). Sokoto. 21-26, August.

Palincsar, A. S., Anderson, C. A., \& David, Y. M. (1993). Pursuing Scientific Literacy in the Middle Grades through Collaborative Problem Solving. Elementary School Journal, 93(5), 643-658.

Savin-Baden, M. (2000). Facilitating Problem-based Bearning: The Impact of Tutor's Pedagogical Stances. Journal of Excellence in College Teaching, 11(2/3), 97-102.

Scot, S. (2008). Perception of Students Learning Critical Thinking through Debate in a Technology Classroom: A Case Study. The Journal of Technology Studies, 34(1), 39.

Slavin, R. E. (1987). Cooperative Learning and the Cooperative School. Educational Leadership, 45(3), 7-13.

Soller, A., \& Lesgold, A. (2000). Knowledge Acquisition for Adaptive Collaborative Learning Environments. Proceedings of the AAAI Fall Symposium: Learning How to Do Thing (pp. 57-64). Cambridge: MIT. Press.

Soller, A., Lesgold, A., Linton, F., \& Goodman, B. (1999). What Makes Peer Interaction Effective? Modeling Effective Communication in an Intelligent. Paper presented at the Fall Symposium on Psychological Models of Communication in Collaborative Systems, North Falmouth, Massachusetts, USA. November 5-7

Surif, J., Ibrahim, N. H., \& Mokhtar, M. (2013). Implementation of Problem-Based Learning in Higher Education Institutions and its Impact on Students Learning. Proceedings of the 4th International Research Symposium on Problem-Based Learning (pp. 66-73). Universiti Teknologi Malaysia, Kuala-Lumpur. 2-3, July.

Tan Y. P., \& Arshad, M. Y. (2011).Problem-Based Learning: Implementation Issues in Malaysia Secondary School Science Classroom. A paper presented at the $4^{\text {th }}$ International Conference of Science and Mathematics Education (pp. 1-10).Universiti Teknologi Malysia. Johor Bahru. 15-17, November.

Tan, Y. P., \& Arshad, M. Y. (2014). Teacher and Student Questions: A Case Study of Malaysia Secondary School Problem-Based Learning. Asian Social Science, 10(4), 174-182. http://dx.doi.org/10.5539/ass.v10n4p174

\section{Copyrights}

Copyright for this article is retained by the author (s), with first publication rights granted to the journal.

This is an open-access article distributed under the terms and conditions of the Creative Commons Attribution license (http://creativecommons.org/licenses/by/3.0/). 